\title{
Nitrogen and dissolved organic carbon (DOC) losses from an artificially drained grassland on organic soils
}

\author{
B. Tiemeyer ${ }^{1}$ and P. Kahle ${ }^{2}$ \\ ${ }^{1}$ Thünen Institute for Climate-Smart Agriculture, Bundesallee 50, 38116 Brunswick, Germany \\ ${ }^{2}$ Faculty of Agricultural and Environmental Sciences, Rostock University, Justus-von-Liebig Weg 6, 18051 Rostock, Germany \\ Correspondence to: B. Tiemeyer (baerbel.tiemeyer@ti.bund.de)
}

Received: 29 January 2014 - Published in Biogeosciences Discuss.: 25 February 2014

Revised: 12 June 2014 - Accepted: 26 June 2014 - Published: 6 August 2014

\begin{abstract}
Nitrate-nitrogen $\left(\mathrm{NO}_{3}-\mathrm{N}\right)$ as well as dissolved organic carbon (DOC) and nitrogen (DON) concentrations and losses were studied for three and two years, respectively, in a small catchment dominated by a degraded peatland used as intensive grassland. Concentrations in the shallow groundwater were spatially and temporally very variable, with $\mathrm{NO}_{3}-\mathrm{N}$ being the most dynamic component $\left(7.3 \pm 12.5 \mathrm{mg} \mathrm{L}^{-1}\right)$ and ranging from 0 to $79.4 \mathrm{mg} \mathrm{L}^{-1}$. Average $\mathrm{NO}_{3}-\mathrm{N}$ concentrations of $10.3 \pm 5.4 \mathrm{mg} \mathrm{L}^{-1}$ (0 to $25.5 \mathrm{mg} \mathrm{L}^{-1}$ ) in the ditch draining the catchment and annual $\mathrm{NO}_{3}-\mathrm{N}$ losses of 19,35 and $26 \mathrm{~kg} \mathrm{ha}^{-1}$ confirmed drained peatlands as an important source of diffuse $\mathrm{N}$ pollution. The highest $\mathrm{NO}_{3}-\mathrm{N}$ losses occurred during the wettest year. Resulting from concentration of $2.4 \pm 0.8 \mathrm{mg} \mathrm{L}^{-1}$ ( 0.7 to $6.2 \mathrm{mg} \mathrm{L}^{-1}$ ), DON added a further 4.5 to $6.4 \mathrm{~kg} \mathrm{ha}^{-1}$ to the $\mathrm{N}$ losses and thus formed a relevant $(15 \%)$ component of the total N losses. Ditch DOC concentrations of $24.9 \pm 5.9 \mathrm{mg} \mathrm{L}^{-1}$ (13.1 to $47.7 \mathrm{mg} \mathrm{L}^{-1}$ ) resulted in DOC losses of $66 \mathrm{~kg} \mathrm{ha}^{-1}$ in the wet year of 2006/2007 and $39 \mathrm{~kg} \mathrm{ha}^{-1}$ in the dry year of 2007/2008. Ditch DOC concentration were lower than the groundwater DOC concentration of $50.6 \pm 15.2 \mathrm{mg} \mathrm{L}^{-1}$ (14.9 to $88.5 \mathrm{mg} \mathrm{L}^{-1}$ ). Both DOC and $\mathrm{N}$ concentrations were governed by hydrological conditions, but $\mathrm{NO}_{3}-\mathrm{N}$ reacted much faster and clearer on rising discharge rates than DOC, which tended to be higher under drier conditions. In the third year of the study, the superposition of a very wet summer and land use changes from grassland to arable land in a part of the catchment suggests that, under re-wetting conditions with a high groundwater table in summer, $\mathrm{NO}_{3}-\mathrm{N}$ would diminish quickly, while DOC would remain on a similar level. Further intensification of the land use, on the other hand, would increase $\mathrm{N}$ losses to receiving water bodies.
\end{abstract}

\section{Introduction}

Worldwide, peatlands are a major store of organic carbon and nitrogen (Gorham, 1991). In the course of the intensification of agriculture, most of the peatlands in western Europe as well as in Mecklenburg-Vorpommern (north-eastern Germany) have been drained. Nowadays, the majority of the peatlands in Germany are used as grassland (UBA, 2012). Lowering the groundwater table by drainage leads to deleterious effects such as peat degradation (Zeitz and Velty, 2002); loss of biodiversity (Succow and Joosten, 2001); and high emissions of greenhouse gases, especially carbon dioxide (Höper, 2002; Limpens et al., 2008; UBA, 2012). Furthermore, the water-purifying function of lowland peatlands is lost as drainage frequently turns them from a nutrient sink into a nutrient source (Holden et al., 2004).

Due to the waterlogged conditions, nitrate $\left(\mathrm{NO}_{3}^{-}\right)$concentrations in undisturbed peatlands are - if present at all - very low (Adamson et al., 1998; Åström et al., 2004). In contrast, high nitrate concentrations in the porewater of drained peatlands are caused by the aeration of the peat and subsequent mineralisation and nitrification of organic nitrogen (Holden et al., 2004; Olde Venterink et al., 2002; Sapek et al., 2007). These processes will be particularly intensive in the case of low groundwater levels (Hacin et al., 2011; Martin et al., 1997) and of high amplitudes of the groundwater level fluctuations, which are typical of degraded peatlands due to the altered hydraulic properties of the peat (Zeitz and Velty, 2002). Nitrogen supply by fertilisation or atmospheric deposition can enhance mineralisation (Ross et al., 1995; Verhoeven et al., 1996). In heavily drained peatlands under intensive grassland use, net $\mathrm{N}$ mineralisation rates 
$>200 \mathrm{~kg} \mathrm{Nha}^{-1} \mathrm{a}^{-1}$ have been measured (Okruszko, 1989; Van Beek et al., 2007). However, many of these studies have been conducted on the scale of lysimeters (Behrendt et al., 1996; Roberts et al., 1986; Ross et al., 1995) or soil cores (Cabezas et al., 2012; Martin et al., 1997; Olde Venterink et al., 2002). The actual $\mathrm{NO}_{3}^{-}$losses depend on the water pathways, and denitrification during the passage of nitraterich water through zones of saturated peat might reduce the amount of $\mathrm{NO}_{3}^{-}$reaching surface water bodies (Sapek et al., 2007). However, although the principle processes are well known, actual numbers of $\mathrm{NO}_{3}-\mathrm{N}$ losses for small catchments are hard to find in the literature.

At the same time, the European Water Framework Directive (European Parliament and European Council, 2000) demands a "good ecological status" of all water bodies. Diffuse nutrient pollution has been found to be a major obstacle to this goal. As nitrate is effectively reduced under wet conditions (Cabezas et al., 2012), re-wetting peatlands has been suggested as a measure to both reduce diffuse pollution originating from degraded peatlands themselves and to clean nutrient-rich water from upstream areas (Davidsson et al., 2002; Trepel, 2010; Vikman et al., 2010). Especially strongly degraded peat seems to have a high denitrification and $\mathrm{N}$ retention potential when re-wetted (Cabezas et al., 2012; Davidsson et al., 2002), although other studies have found ongoing mineralisation under these conditions (Olde Venterink et al., 2002). Besides combating diffuse pollution as required by legislative efforts, the monetisation of ecosystem services of peatlands is increasingly coming into the focus of attention (Russi et al., 2013; Trepel, 2010). Both topics need baseline data for drained peatlands against which improvements by re-wetting measures can be evaluated.

Dissolved organic carbon (DOC) may play an important role in the carbon cycle of peatlands and beyond: DOC losses may form an important part of the carbon balance (Dinsmore et al., 2010; Rowson et al., 2010), act as a transport vector for organically bound substances (Rothwell et al., 2007) and influence biogeochemical cycling in and drinking water quality of the receiving water bodies (Chow et al., 2003). While the governing processes and influence factors for nitrate are quite well known, the effects of drainage and re-wetting on DOC and dissolved organic nitrogen (DON) losses are less clear. Several factors determining DOC concentrations in the porewater and the groundwater of peatlands - such as the groundwater levels (Frank et al., 2014), the temperature (Koehler et al., 2009), the ionic strength (Evans et al., 2006) and the pH (Clark et al., 2005) - have been proposed, but effects are sometimes confounding or interacting. For example, higher temperatures might cause a water table drawdown, subsequent sulphate release and thus a change in both the ionic strength and the $\mathrm{pH}$ (Clark et al., 2005). Furthermore, as in the case of nitrate, different processes govern DOC concentrations within and losses from the peatland. While DOC release and consumption are mainly controlled by biogeochemical processes, hydrology - particularly the water bal- ance - becomes an important factor when comparing losses from different peatlands (Fraser et al., 2001; Gibson et al., 2009). Drainage has frequently been found to increase DOC concentrations in peatlands due to increased microbial activity (Frank et al., 2014). In contrast to these results, some boreal peatlands have shown decreasing DOC concentrations after drainage (Åström et al., 2004).

Overall, most authors suggest re-wetting as an effective measure to reduce DOC concentrations and/or losses (Frank et al., 2014; Wallage et al., 2006). However, some studies have found - sometimes temporary - increasing DOC concentrations or losses after re-wetting, especially for highly degraded peat soils (Kalbitz and Geyer, 2002). These field observations are supported by laboratory studies (Cabezas et al., 2013; Zak and Gelbrecht, 2007), so at least some precaution should be taken when recommending re-wetting to reduce DOC concentrations. As most field studies on DOC focus on bogs and/or re-wetted sites (Austnes et al., 2010; Dinsmore et al., 2010; Dawson et al., 2002; Frank et al., 2014; Fraser et al., 2001; Gibson et al., 2009; Wallage et al., 2006), there is a distinct lack of baseline data for temperate lowland peatlands with fen peat under agricultural use. Even less is known on DON than on DOC, although some studies suggest that DOC and DON do not necessarily follow the same dynamics (Kalbitz and Geyer, 2002).

In this study, we want to show how hydro-meteorological conditions influence the DOC, $\mathrm{NO}_{3}-\mathrm{N}$ and DON concentrations in and losses from an artificially drained lowland catchment with organic soils. The catchment represents a situation typical for central Europe - artificially drained intensive grassland - and thus provides baseline data lacking up to now. Due to extreme weather conditions and land use changes from permanent grassland to arable land during the course of the study, we can estimate how the hydrochemical dynamics might develop under a changing hydrological regime or intensified agriculture.

\section{Material and methods}

\subsection{The study site}

The study area is situated in the Pleistocene lowlands of north-eastern Germany $(10 \mathrm{~km}$ southeast of the city of Rostock). The landscape is characterised by gently sloping ground moraines and by peatlands in the river and stream valleys. Long-term mean annual precipitation, reference crop evapotranspiration and temperature are $642 \mathrm{~mm}, 561 \mathrm{~mm}$ and $8.7^{\circ} \mathrm{C}$, respectively. The study site is a small ( 85 ha) catchment of a drainage ditch (Fig. 1). The catchment consists of intensive grasslands mainly on organic soils and arable land on mineral soils. The boundary between mineral and organic soils was determined by soil augering (Blume, 2005). Organic soils cover around $50 \%$ of the catchment. 
Due to a hydrogeologically complex setting, the peatland has developed as a combination of terrestrialisation and percolation mires (Edom et al., 2010). The properties and depths of the organic soils are spatially highly variable, but they are all drained by ditches and occasional tile drains. Peat thickness varies between a few $\mathrm{cm}$ and $1.50 \mathrm{~m}$. The peat is partially underlain by a confining layer of either calcareous or organic gyttja and partially directly overlies an aquifer of coarse sand. The soil organic carbon (SOC) content of the topsoil varies between 8 and $409 \mathrm{~g} \mathrm{~kg}^{-1}$ (Tiemeyer et al., 2007). This is reflected by a variety of soil types such as Eutric and Sapric Histosols, Histic Gleysols and Histic Stagnosols (World Reference Base for Soil Resources (WRB) classification; IUSS Working Group WRB, 2007). Nowadays, the hydrology of the peatland is heavily influenced by anthropogenic changes by tile drains and ditches, which partially cut into the mineral layers. After a particularly wet summer (2007), some of the ditches and drains were renovated (Fig. 1).

At the beginning of the study, the organic soils were used as grassland. The grassland is managed as an intensive meadow with four to five cuts per year. The average yield of grass is $330 \mathrm{dtha}^{-1} \mathrm{a}^{-1}$ (fresh mass). The sward is regularly re-sown and mainly consists of ryegrass (Lolium perenne L.), common meadow grass (Poa pratensis L.) and couch grass (Elymus repens L.). In wetter parts, meadow foxtail (Alopecurus pratensis L.), reed canary grass (Phalaris arundinacea L.) and Yorkshire fog (Holcus lanatus L.) are found as well. In spring 2007, a part of the grassland was ploughed and converted to arable land for maize (Zea mays L.) production (Fig. 1).

Until 2007, the arable land in the catchment was situated on mineral soils such as Luvisols and Cambisols, which are not artificially drained. The arable land is used for intensive conventional crop production dominated by winter wheat (Triticum aestivum L.), winter rape (Brassica napus L.), winter barley (Hordeum vulgare L.) and maize. At the grassland, nitrogen was applied only in the form of mineral fertiliser, while cattle slurry was also used for the arable land. Table 1 summarises the field nitrogen budget comprising fertilisation, harvest and atmospheric deposition according to Behrendt (1996). Values for volatile losses and the nutrient contents of the mineral fertilisers, of the harvested crops and of the crop residues were taken from MELFF MV (2004). The amounts and dates of fertiliser application, the crop yields and the nutrient content of the organic fertiliser were provided by the farmer. Details of the budget calculation are described by Tiemeyer et al. (2006).

\subsection{Hydrological measurements and sampling}

At the catchment outlet (Fig. 1), a sampling station measured the water level via a pressure sensor (UGT GmbH, Müncheberg, Germany) and collected, depending on the flow conditions, daily to weekly composite ( $3 \mathrm{~h}$ sampling inter-

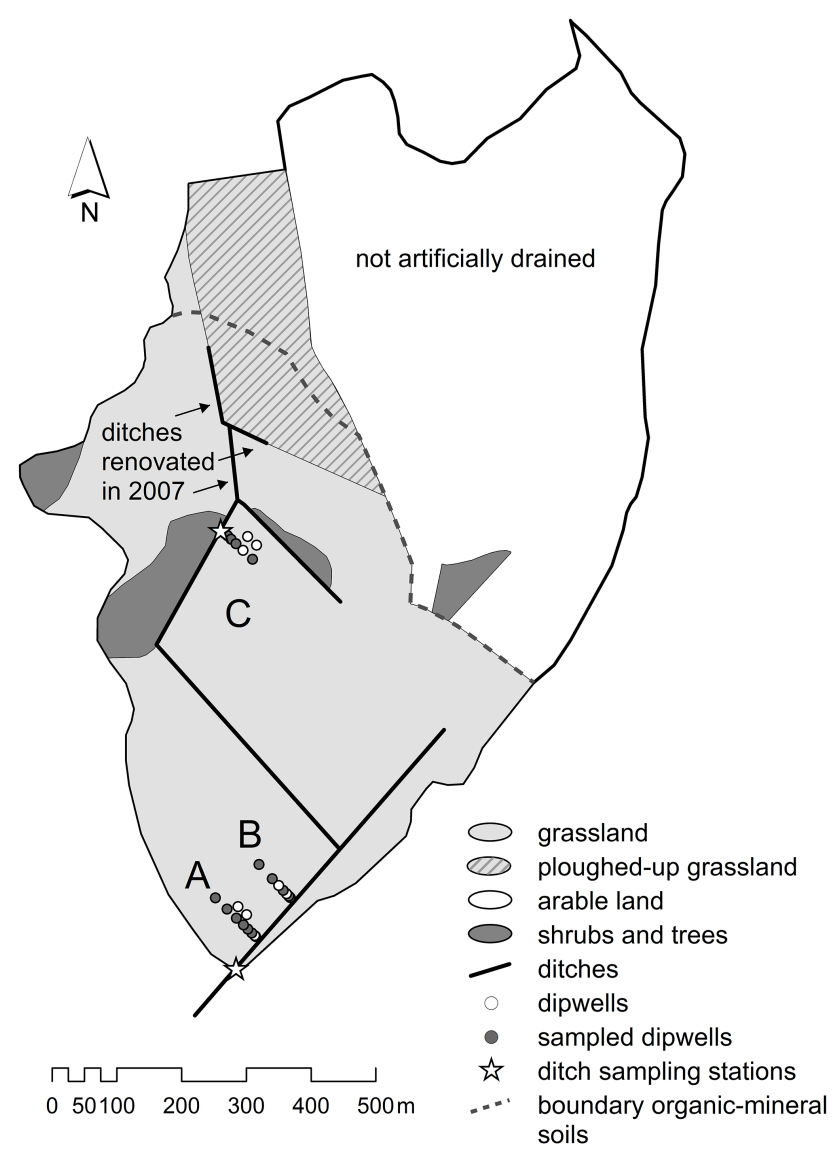

Figure 1. The study area.

val) water samples with an automatic sampler (Teledyne Isco, Inc., Lincoln, NE, USA). The discharge was measured weekly with an inductive flow meter (Flo-MateTM, MarshMcBirney, Inc., Frederick, MD, USA) to develop a rating curve. Air temperature, humidity, wind speed (UGT GmbH, Müncheberg, Germany) and precipitation (Seba Hydrometrie $\mathrm{GmbH}$, Kaufbeuren, Germany) were recorded at a climate station at a distance of $1.5 \mathrm{~km}$.

The dip wells (DWs) used in this study are PVC pipes with an internal diameter of $5.2 \mathrm{~cm}$, which are slotted and filtered with a nylon mesh at a depth of 0.5 to $1.5 \mathrm{~m}$ below ground. Twelve dip wells were installed in transects A and $\mathrm{B}$ on shallow organic soils and six dip wells in transect $C$ on deep organic soils. Topsoil $(0-30 \mathrm{~cm})$ SOC content is $112 \pm 114$ (transect A), $211 \pm 116$ (transect B) and $368 \pm 39 \mathrm{~g} \mathrm{~kg}^{-1}$ (transect C) (Tiemeyer et al., 2007). The dip wells were sampled weekly during the winter season (November to April), while the groundwater level was additionally measured fortnightly during summer (May to October) unless a DW fell dry. Groundwater samples were taken with a bailer after nearly emptying the DW and allowing the water level to recover. The bailer was rinsed with deionised water after each use. Sample bottles were filled immediately 
Table 1. Management.

\begin{tabular}{lccc}
\hline Period & $\begin{array}{c}\text { N } \\
\text { fertilisation } \\
\text { grassland }\end{array}$ & $\begin{array}{c}\text { N field } \\
\text { balance } \\
\text { grassland }\end{array}$ & $\begin{array}{c}\text { N field } \\
\text { balance } \\
\text { catchment }\end{array}$ \\
\cline { 2 - 4 } & & $\mathrm{kg} \mathrm{ha}^{-1}$ & \\
\hline $2002 / 2003$ & 230 & 90 & 93 \\
$2003 / 2004$ & 230 & 90 & 100 \\
$2004 / 2005$ & 228 & 87 & 103 \\
$2005 / 2006$ & 184 & 54 & 92 \\
$2006 / 2007$ & 159 & 62 & 49 \\
$2007 / 2008$ & 240 & 102 & 54 \\
\hline
\end{tabular}

and completely. In addition to the groundwater samples and the samples at the catchment outlet, weekly grab samples were taken from the ditch adjacent to transect C (Fig. 1). Samples were not further treated.

Details on the study site and the field methods can be found in Tiemeyer et al. (2007), who discussed the spatial variability of a number of ions (but of neither DOC nor DON) in the groundwater during winter 2005/2006. Here, we report on results from November 2005 to October 2008, and focus on nitrogen and DOC. To highlight the effects of extreme climatic conditions and land use change in the catchment, the results of the first year are also included in this study.

\subsection{Laboratory methods}

Nitrate $\left(\mathrm{NO}_{3}^{-}\right)$and ammonium $\left(\mathrm{NH}_{4}^{+}\right)$were analysed by ion chromatography (Metrohm GmbH, Herisau, Switzerland) with chemical suppression for anion analysis. Measurements were accepted when reference standards were within $1 \%$ of the desired value.

The electrical conductivity (EC) and the $\mathrm{pH}$ of the water samples were measured with the probes LF 196 and pH 196 (WTW, Weilheim, Germany). Unfortunately, EC and especially $\mathrm{pH}$ measurements are missing for a number of samples.

DOC and total nitrogen (TN) were determined from filtered samples $(0.45 \mu \mathrm{m}$ PET filter, Macharey-Nagel, Dühren, Germany) by combustion and infrared detection (DIMATOC $^{\odot}$ 2000; Dimatec GmbH, Essen, Germany) and chemiluminescence detection (TN-100; Mitsubishi Chemical Corporation, Kanagawa, Japan), respectively. DOC and $\mathrm{TN}$ were measured at three to five replicates each. Measurements were accepted when the coefficient of variation of the replicate measurements was $<2 \%$. The errors of the reference standards needed to be $<5 \%$.

DON was calculated as the difference of TN and mineral $\mathrm{N}\left(\mathrm{NO}_{3}-\mathrm{N}+\mathrm{NH}_{4}-\mathrm{N}\right)$. DOC and $\mathrm{TN}$ concentrations were determined for ditch samples of the hydrological years $2006 / 2007$ and 2007/2008. Additionally, DOC in the ground- water from transect $\mathrm{C}$ was measured at selected $(n=30)$ samples from 2006/2007 and at all samples from 2007/2008.

\subsection{Statistics}

All statistical analyses were carried out in R ( $\mathrm{R}$ Core Team, 2013). To account for the residence time of the water and to identify additional explanatory parameters for the DOC, $\mathrm{NO}_{3}-\mathrm{N}$ and DON concentrations, a cross-correlation analysis of the concentrations in the ditch and the average discharge over the last 1 to 90 days was conducted. The discharge was square-root-transformed before analysis to improve the linearity between the concentrations and the discharge.

During the study period, there was a relatively dry and a very wet period. Differences between these periods were evaluated with generalised least square (GLS) and linear mixed effects (LME) models from the nlme (Linear and Nonlinear Mixed Effects Models) package (Pinheiro et al., 2013). Analyses were done separately for concentrations (c) of DOC, DON and $\mathrm{NO}_{3}-\mathrm{N}$. In a first step, a GLS model explaining the concentrations only by the fixed effect period was set up. Following the procedure outlined by Zuur et al. (2009), a suitable variance structure was added next. Different variance structures (varIdent, varPower and varExp) were tested. In the case of the concentrations in the groundwater, adding a random structure (i.e. using a LME model instead of a GLS model) with dip well as a random factor was additionally tested. As a further step, a first-order autocorrelation structure (corAR1) was added. The improvement of the model due to each addition was evaluated by the Akaike information criterion (AIC) and, after re-fitting the model with the maximum likelihood method, by an analysis of variance (ANOVA) between the first model and the model in question. Additionally, at each step, the residuals were visually checked for homogeneity. An example for the resulting model is given in Eq. (1).

$\operatorname{gls}(c \sim$ period, weights $=\operatorname{varIdent}($ form $=\sim 1 \mid$ period $)$,

$\operatorname{cor}=\operatorname{corAR} 1($ form $=\sim$ date $\mid$ period $)$ )

The final model was then tested against a reference model in which the fixed effect period was replaced by 1 , which represents the mean of all data. If the AIC for the reference model was significantly higher, a significant difference between the two periods is assumed. For this final ANOVA, $p$ values are reported.

Influence factors on the concentrations at the catchment outlet and in the groundwater were also analysed with GLS and LME models following the same general procedure starting with the most complex model including all meaningful interactions (Zuur et al., 2009). Next, the necessity of including the random factor dip well (in the case of the groundwater concentrations) was evaluated followed by the choice of suitable variance and autocorrelation structures. Both a variance and an autocorrelation structure were necessary for 
nearly all model setups. Afterwards, the model structure was reduced stepwise depending on the AIC and the parameter significance: if an ANOVA indicated that the reduced model is not significantly worse than the full model, a parameter or a parameter interaction could be dropped. As GLS and LME models cannot deal with missing data, separate models had to be set up for the complete data set and those data with $\mathrm{pH}$ and EC measurements. To evaluate the explanatory power of the final models, the Nash-Sutcliffe coefficient (NSC) or "model efficiency" was calculated (Nash and Sutcliffe, 1970). The NSC can range from $-\infty$ to 1 . A value of 1 indicates a perfect fit between the modelled and the measured data, while values lower than zero mean that the average of the measured data is a better predictor than the model itself.

\section{Results}

\subsection{Hydrology}

Table 2 summarises the hydrological conditions during the study period. While the first hydrological year (1 November 2005 to 31 October 2006) was fairly average, the following two years were unusual. Both years were warmer than average, and annual precipitation sums of 934 and $554 \mathrm{~mm}$ marked exceptionally wet and dry conditions. While the precipitation and the discharge were similar during the winter periods, the summer made the difference between the last two years. Given the long-term summer precipitation average of $372 \mathrm{~mm}$, the summer of 2007 was extraordinarily rainy with a precipitation of $551 \mathrm{~mm}$. In contrast to other summers during which the ditch fell dry in May or June (Fig. 2), the summer discharge in 2007 (91 mm) was higher than that of dry winters (Tiemeyer et al., 2007). On an annual basis, 24 to $32 \%$ of the precipitation left the catchment as discharge. In the following, 1 November 2005 to 31 May 2007 is referred to as the "dry period", and the remainder of the study period as the "wet period". Technically, the summer of 2008 is dry again, but as both the ditch and the dip wells quickly dried out there are nearly no data on this summer period.

Whereas during winter the groundwater level was frequently near the ground surface, it dropped during dry spells deeper than $1.00 \mathrm{~m}$ even in the wettest places, demonstrating the heavy disturbance of the peatland. The wet summer of 2007 had a lasting effect even on the groundwater table in the subsequent winter, when the average water table depth (WTD) was, despite slightly less precipitation, higher and more homogenous in time than during the preceding winters (Fig. 4, Table 2). Thus, the wet summer might anticipate possible short-term effects of re-wetting.

Due to drainage, soil and topographical heterogeneity, there was high spatial variability of the WTD, with minimum and maximum averages over the whole study period of 0.27 (DW 13) and $1.13 \mathrm{~m}$ (DW 4), respectively (Fig. 4). In summer 2008, groundwater wells quickly fell dry or had to

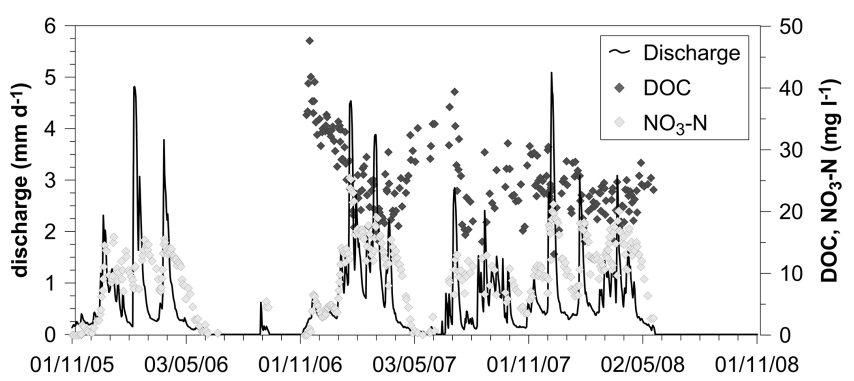

Figure 2. Discharge $\left(\mathrm{mm} \mathrm{d}^{-1}\right)$ and concentrations $\left(\mathrm{mg} \mathrm{L}^{-1}\right)$ of dissolved organic carbon (DOC) and nitrate-nitrogen $\left(\mathrm{NO}_{3}-\mathrm{N}\right)$ in the ditch.

be removed. Due to the spatially heterogeneous groundwater table dynamics, heterogeneous biogeochemical processes can be expected, especially as not only the mean WTD but also the amplitude differed even in the wetter winters as a result of heterogeneous soil properties. The ditch integrates all these responses together with groundwater flow from the non-drained part of the catchment (and, given the heterogeneous geological situation of the area, possibly also deeper groundwater).

\subsection{DOC and nitrogen concentrations groundwater}

An overview of the DOC and $\mathrm{NO}_{3}-\mathrm{N}$ concentrations is given in Table 3 . The overall average $( \pm$ standard deviation) DOC concentration of all measurements in the dip wells was $50.6 \pm 15.2 \mathrm{mg} \mathrm{L}^{-1}$. The spatial heterogeneity was relatively weak; in single dip wells, average DOC concentrations over the complete study period between $40.7 \pm 11.7$ and $60.1 \pm 13.6 \mathrm{mg} \mathrm{L}^{-1}$ were measured. During the winter of 2006/2007, overall average concentrations were $46.8 \pm 17.9 \mathrm{mg} \mathrm{L}^{-1}$. As shown in Fig. 3, the wet conditions from June 2007 to April 2008 had no clear effect on the groundwater DOC concentrations in the following winter $\left(51.4 \pm 14.6 \mathrm{mg} \mathrm{L}^{-1}\right)$. This was confirmed by comparing GLS models including or excluding the hydrological period as a fixed effect $(p=0.30)$.

The final GLS model $(\mathrm{NSC}=0.42$ ) for the DOC concentrations in the groundwater $(n=180)$ was complex. Although the subset of data with $\mathrm{pH}$ measurements was only slightly smaller $(n=162)$, the resulting GLS model was even more complex and had an NSC of 0.68. The variables contained in the final models are shown in Table 5.

Overall, the $\mathrm{NO}_{3}-\mathrm{N}$ concentrations in the groundwater were highly variable both in space and time $\left(7.3 \pm 12.5 \mathrm{mg} \mathrm{L}^{-1}\right)$. Minimum and maximum concentrations were 0 and $79.4 \mathrm{mg} \mathrm{L}^{-1}$, respectively. The high standard deviation of all $\mathrm{NO}_{3}-\mathrm{N}$ concentrations is caused by the occurrence of many rather low and a few very high values (Fig. 4). During the first and the second winter, $\mathrm{NO}_{3}-\mathrm{N}$ concentrations were partially extremely high (Fig. 4). During the first year of the study period, $\mathrm{NO}_{3}-\mathrm{N}$ concentrations 
Table 2. Hydrological and meteorological conditions during the study period: precipitation $(P)$, reference crop evapotranspiration $\left(\mathrm{ET}_{\mathrm{c}}\right)$, discharge at the outlet $(Q)$, mean and standard deviation (SD) water table depth (WTD) and temperature $(T)$. Long-term averages: German Weather Service raster data 1990-2011. No groundwater level data are available for summer 2008 (n.d.: not determined).

\begin{tabular}{|c|c|c|c|c|c|c|}
\hline \multirow{3}{*}{ Period } & \multirow[t]{3}{*}{$P$} & \multirow[t]{2}{*}{$\mathrm{ET}_{\mathrm{c}}$} & \multirow[t]{2}{*}{$Q$} & \multicolumn{2}{|c|}{ WTD } & \multirow[b]{3}{*}{${ }^{\circ} \mathrm{C}$} \\
\hline & & & & mean & SD & \\
\hline & & \multicolumn{2}{|l|}{$\mathrm{mm}$} & \multicolumn{2}{|c|}{$\mathrm{m}$} & \\
\hline $2005 / 2006$ & 701 & 507 & 165 & 0.74 & 0.18 & 8.9 \\
\hline Winter & 289 & 68 & 158 & 0.51 & 0.18 & 1.7 \\
\hline Summer & 413 & 439 & 17 & 0.98 & 0.19 & 16.0 \\
\hline $2006 / 2007$ & 934 & 485 & 270 & 0.58 & 0.22 & 10.0 \\
\hline Winter & 383 & 124 & 179 & 0.51 & 0.17 & 6.0 \\
\hline Summer & 551 & 361 & 91 & 0.65 & 0.28 & 14.0 \\
\hline 2007/0208 & 554 & 515 & 180 & n.d. & n.d. & 9.0 \\
\hline Winter & 346 & 99 & 177 & 0.37 & 0.10 & 4.0 \\
\hline Summer & 208 & 416 & 4 & n.d. & n.d. & 13.9 \\
\hline Long-term mean & 642 & 561 & - & - & - & 8.7 \\
\hline Winter & 271 & 130 & - & - & - & 3.1 \\
\hline Summer & 372 & 431 & - & - & - & 14.3 \\
\hline
\end{tabular}

generally rose with rising GW levels (Tiemeyer et al., 2007), although the concentration levels differed strongly between the single dip wells. These patterns were confirmed during the second year: the $\mathrm{NO}_{3}-\mathrm{N}$ levels were again very different between the dip wells, but the temporal concentration patterns were similar. The spatial heterogeneity reflected by dip well mean concentrations of $0.4 \pm 0.8$ to $44.1 \pm 19.7 \mathrm{mg} \mathrm{L}^{-1}$ (dry period) was, especially compared to DOC, very high (Fig. 4). Average ammonium-nitrogen $\left(\mathrm{NH}_{4}-\mathrm{N}\right)$ concentrations were near zero.

Although some small concentration peaks still occurred in the third winter after rising groundwater levels, the wet summer of 2007 had completely changed the $\mathrm{NO}_{3}-\mathrm{N}$ concentration dynamics in the groundwater (Fig. 4). While winter groundwater levels remained similar, overall average $\mathrm{NO}_{3}-$ $\mathrm{N}$ concentrations dropped from $9.7 \pm 14.3 \mathrm{mg} \mathrm{L}^{-1}$ during the dry period to $2.5 \pm 4.8 \mathrm{mg} \mathrm{L}^{-1}$ in the wet period. This statistically significant $(p=0.002)$ change was especially evident at dip wells associated with a high SOC content, furthermost at those two dip wells in transect $\mathrm{C}$ (deep peat) where average $\mathrm{NO}_{3}-\mathrm{N}$ concentrations of $44.1 \pm 19.7$ and $25.4 \pm 12.8 \mathrm{mg} \mathrm{L}^{-1}$ in the first two winters decreased to $0.8 \pm 1.2$ and $1.5 \pm 2.2 \mathrm{mg} \mathrm{L}^{-1}$ in the third winter (Fig. 4). As a result, the spatial heterogeneity (dip well means: $0.2 \pm 0.1$ to $15.0 \pm 2.7 \mathrm{mg} \mathrm{L}^{-1}$ ) was strongly reduced compared to the dry period. $\mathrm{NH}_{4}-\mathrm{N}$ concentrations were still low $\left(0.4 \pm 0.7 \mathrm{mg} \mathrm{L}^{-1}\right)$.

The final LME model $(\mathrm{NSC}=0.45)$ for the $\mathrm{NO}_{3}-\mathrm{N}$ concentrations was also complex (Table 5). Besides the period, the depth to the groundwater table, the change of the ground-

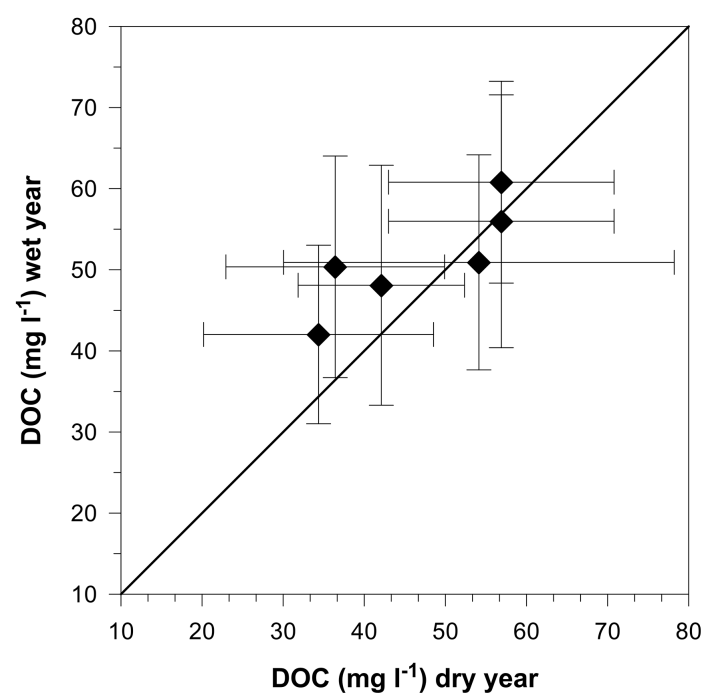

Figure 3. Average ( \pm standard deviation) DOC concentrations in the dry winter of 2006/2007 and in the wet winter of 2007/2008 in the dip wells of transect $\mathrm{C}$.

water table and the nitrogen content of the peat were the most important parameters. Higher temperatures intensified these effects.

\subsection{DOC and nitrogen concentrations in the ditch}

Discharge, DOC and $\mathrm{NO}_{3}-\mathrm{N}$ concentrations in the ditch are shown in Fig. 2, and an overview of the DOC, DON and $\mathrm{NO}_{3}-\mathrm{N}$ concentrations is given in Table 4. DOC concentrations in the ditch $\left(24.9 \pm 5.9 \mathrm{~m} \mathrm{~L}^{-1}\right)$ were much lower than in the groundwater $\left(50.6 \pm 15.2 \mathrm{mg} \mathrm{L}^{-1}\right)$. While DOC concentrations were slightly lower during the wet period than during the dry period (Table 3 ), this difference was only significant on a low level $(p=0.049)$. Visually, the DOC concentrations seem to be higher at the beginning of the discharge period and lower during discharge events. However, the instantaneous discharge was not included in the final model for the DOC concentrations in our catchment. To account for the residence time of the water, a cross-correlation analysis of the DOC, $\mathrm{NO}_{3}-\mathrm{N}$ and DON concentrations in the ditch and the average discharge had been conducted. For the DOC concentrations, the maximum correlation coefficient was found for an average discharge over the last 70 days (Fig. 5). Accordingly, the average discharge over the last 70 days $\left(Q_{70}\right)$ was the only significant parameter in the final GLS models for the full data set $(n=237)$ and the data set with EC measurements $(n=224)$. The NSC of these models was 0.48 . No significant effects of the temperature, the instantaneous discharge or any interactions could be determined. The data set including $\mathrm{pH}$ measurements was much smaller $(n=88)$, but had to be described by a more complicated GLS model $(\mathrm{NSC}=0.54)$ including $Q, Q_{70}$, temperature, $\mathrm{pH}$ and $\mathrm{EC}$ as well as interaction between $Q$ 
Table 3. Dissolved organic carbon (DOC) and nitrate-nitrogen $\left(\mathrm{NO}_{3}-\mathrm{N}\right)$ concentrations in the dip wells (n.d.: not determined).

\begin{tabular}{|c|c|c|c|c|c|c|}
\hline \multirow{3}{*}{ Period } & \multicolumn{3}{|c|}{ DOC } & \multicolumn{3}{|c|}{$\mathrm{NO}_{3}-\mathrm{N}$} \\
\hline & mean $\pm S D$ & $\min$ & $\max$ & mean $\pm \mathrm{SD}$ & $\min$ & $\max$ \\
\hline & \multicolumn{6}{|c|}{$\mathrm{mg} \mathrm{L}^{-1}$} \\
\hline 2005/2006 & n.d. & n.d. & n.d. & $8.8 \pm 12.9$ & 0 & 65.4 \\
\hline $2006 / 2007$ & $46.8 \pm 17.9$ & 14.9 & 80.1 & $10.3 \pm 15.4$ & 0 & 79.4 \\
\hline $2007 / 2008$ & $51.4 \pm 14.6$ & 21.4 & 88.5 & $2.4 \pm 4.6$ & 0 & 21.3 \\
\hline
\end{tabular}
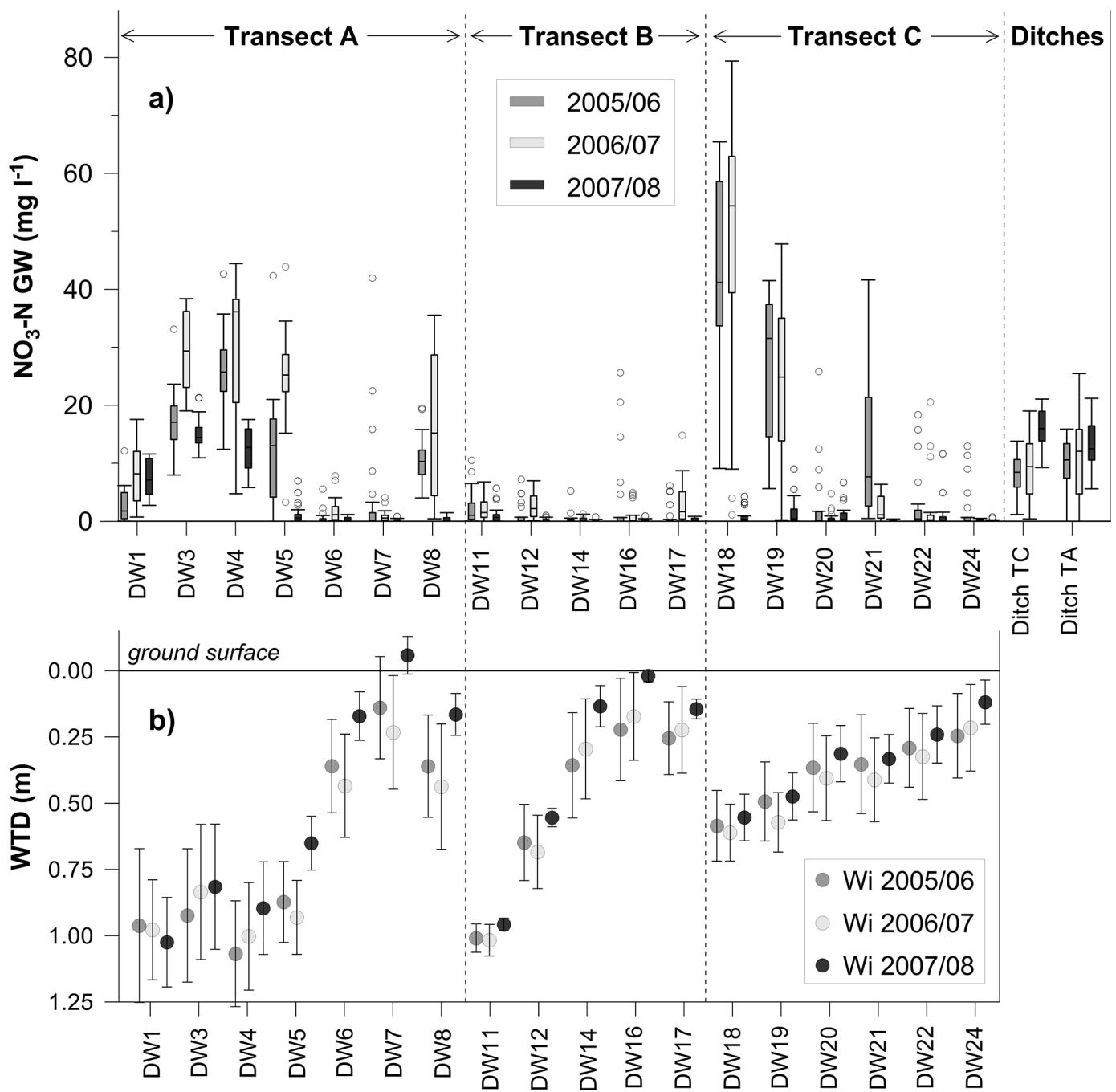

Figure 4. (a) Spatial and temporal variability of nitrate-nitrogen $\left(\mathrm{NO}_{3}-\mathrm{N}\right)$ concentrations in the dip wells. (b) Mean and standard deviation of the water table depth (WTD) during winter. Only sampled dip wells are shown.

and $\mathrm{EC}$ and between $Q$ and $\mathrm{pH}$. Removing the temperature $(\mathrm{NSC}=0.51)$, the $\mathrm{EC}(\mathrm{NSC}=0.25)$ or the $\mathrm{pH}$ value $(\mathrm{NSC}=0.46)$ from the model would all reduce the NSC.

$\mathrm{NO}_{3}-\mathrm{N}$ concentrations in the ditch $\left(10.3 \pm 5.4 \mathrm{mg} \mathrm{L}^{-1}\right)$ were within the range of the concentrations in the dip wells. In contrast to the dip wells, average winter $\mathrm{NO}_{3}-\mathrm{N}$ concentrations in the ditch were increasing during the study pe- riod (Table 4). Therefore, the concentrations during the wet period $\left(11.7 \pm 4.2 \mathrm{mg} \mathrm{L}^{-1}\right)$ were significantly $(p=0.016)$ higher than during the dry period $\left(9.5 \pm 5.9 \mathrm{mg} \mathrm{L}^{-1}\right)$. There was a clear positive correlation between the discharge and the $\mathrm{NO}_{3}-\mathrm{N}$ concentrations (Fig. 2), while the maximum correlation coefficient (Fig. 5) was determined for an average discharge of over 13 days $\left(Q_{13}\right)$. During summer, $\mathrm{NO}_{3}-\mathrm{N}$ 


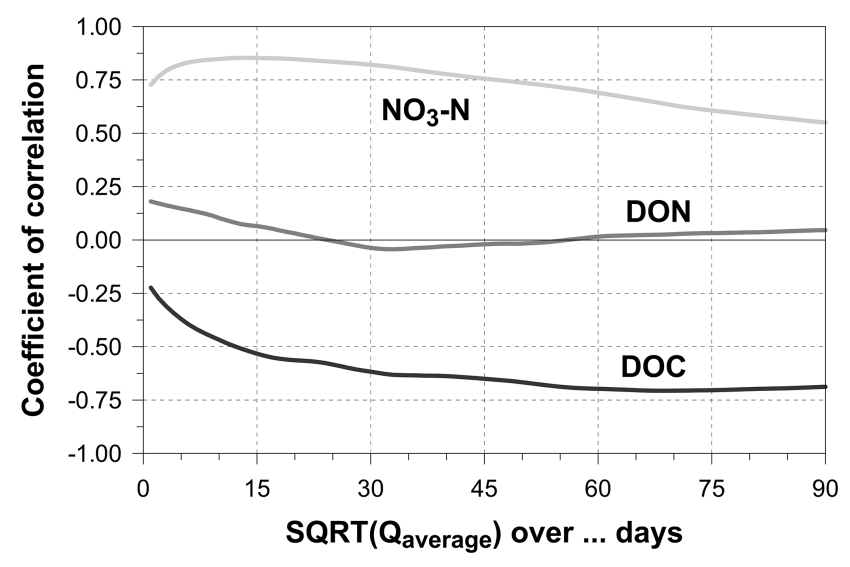

Figure 5. Cross-correlation between the square root of the average discharge $Q_{\text {average }}$ in the ditch and the concentrations of dissolved organic carbon (DOC), dissolved organic nitrogen (DON) and nitrate-nitrogen $\left(\mathrm{NO}_{3}-\mathrm{N}\right)$.

concentrations were clearly lower than during winter in all years, including the wet summer of 2007 (Table 2). The concentration patterns of $\mathrm{NO}_{3}-\mathrm{N}$ and DOC strongly differed, resulting in a negative correlation between DOC and $\mathrm{NO}_{3}-$ $\mathrm{N}$ concentrations, which suggest different transport mechanisms. $\mathrm{NH}_{4}-\mathrm{N}$ was not found at the catchment outlet.

The final GLS model for the full $\mathrm{NO}_{3}-\mathrm{N}$ data set $(n=$ 361 ) included $Q_{13}$ and, with an opposite sign, the instantaneous discharge. When including EC into the analysis $(n=240)$, this parameter and its interaction with $Q_{13}$ were significant according to the procedure outlined by Zuur et al. (2009), but omitting them from the model only reduced the NSC from 0.70 to 0.68 . As in the case of DOC, the data set with $\mathrm{pH}$ measurements was much smaller $(n=91)$ and resulted in a more complex model. However, omitting $\mathrm{pH}$, temperature and EC did only reduce the NSC from 0.74 to 0.70 .

DON concentrations in the ditch of $2.4 \pm 0.8 \mathrm{mg} \mathrm{L}^{-1}$ were relatively low and less variable than $\mathrm{DOC}$ and $\mathrm{NO}_{3}-\mathrm{N}$ (Table 4), although concentrations during the wet period were significantly higher than during the dry period $(p=0.0006)$. The maximum correlation coefficient was found for the discharge on the date of the DON concentration measurement, but all correlation coefficients were very low (Fig. 5). Factors influencing the DON concentrations were difficult to determine; depending on the data subset, the discharge and/or the EC were identified as significant parameters, but the NSC was always only 0.05 .

\subsection{DOC and nitrogen losses}

Seasonal losses of DOC, $\mathrm{NO}_{3}-\mathrm{N}$ and DON are shown in Fig. 6. Annual DOC losses were $66 \mathrm{~kg} \mathrm{ha}^{-1}$ in the wet year of $2006 / 2007$ and $39 \mathrm{~kg} \mathrm{ha}^{-1}$ in the dry year of 2007/2008. In $2006 / 2007$, the winter accounted for $65 \%$ of the DOC losses,

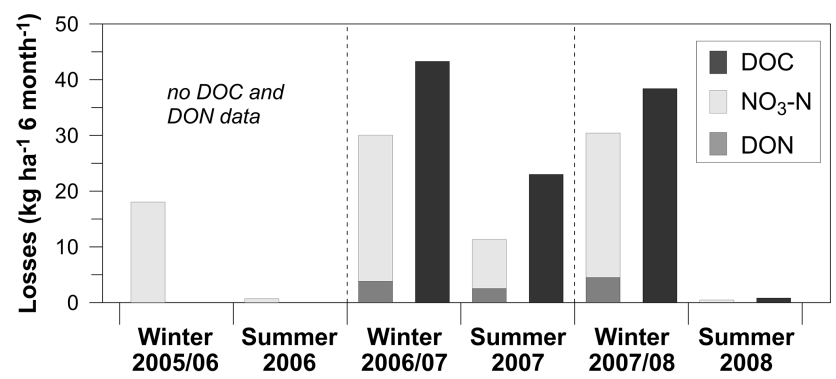

Figure 6. Seasonal losses of dissolved organic carbon (DOC), dissolved organic nitrogen $(\mathrm{DON})$ and nitrate-nitrogen $\left(\mathrm{NO}_{3}-\mathrm{N}\right)$.

whereas in summer 2008 the ditch fell (and remained) dry from May onwards. Thus, in 2007/2008, $98 \%$ of the DOC losses occurred during winter.

Annual total $\mathrm{N}$ losses from the catchment amounted to 19 (without accounting for DON), 42 and $31 \mathrm{~kg} \mathrm{ha}^{-1}$. $\mathrm{NO}_{3}-\mathrm{N}$ was thus the main component of the $\mathrm{N}$ losses. In both years with DON measurements DON accounted for around $15 \%$ of the TN losses (Fig. 6). As the winter is the main discharge period (Table 2) and the $\mathrm{NO}_{3}-\mathrm{N}$ concentrations were lower during the summer months (Table 3), 96, 75 and $98 \%$ of the $\mathrm{NO}_{3}-\mathrm{N}$ losses took place during the winter months.

\section{Discussion}

\subsection{Controls on $\mathrm{DOC}$ and $\mathrm{NO}_{3}-\mathrm{N}$ dynamics in the groundwater: effects of the changed hydrological conditions}

Average DOC concentrations of $50.6 \pm 15.2 \mathrm{mg} \mathrm{L}^{-1}$ are within the typical range of degraded peatlands; Fiedler et al. (2008) measured, for example, average DOC concentrations of $82 \mathrm{mg} \mathrm{L}^{-1}$ in the GW of a deeply drained fen also used as grassland. Kalbitz and Geyer (2002) found mainly lower DOC concentrations $\left(20-76 \mathrm{mg} \mathrm{L}^{-1}\right)$, but their soils did also have lower SOC contents than ours. In drained bog peats, higher DOC concentrations are common (Frank et al., 2014). The wet conditions from June 2007 to April 2008 which are similar to those of recently re-wetted fens - had no clear effect on the groundwater DOC concentrations (Fig. 3). Generally, the effect of re-wetting on DOC concentrations is inconsistent and seems to depend on a number of factors such as the type and degradation status of the peat (Cabezas et al., 2013), the SOC content and the $\mathrm{pH}$. While some authors found considerably higher DOC concentrations in re-wetted, highly degraded fens (Kalbitz and Geyer, 2002), others report significantly lower DOC concentrations after re-wetting (Fiedler et al., 2008; Frank et al., 2014; Wallage et al., 2006) or no change at all (Gibson et al., 2009).

Those dip wells with higher DOC concentrations in the wetter year were situated near the ditch (Fig. 3). Due to the drawdown effect of the ditch, the peat there is probably 
Table 4. Dissolved organic carbon (DOC), nitrate-nitrogen $\left(\mathrm{NO}_{3}-\mathrm{N}\right)$ and dissolved organic nitrogen (DON) concentrations in the ditch (n.d.: not determined).

\begin{tabular}{|c|c|c|c|c|c|c|c|c|c|}
\hline \multirow[t]{3}{*}{ Period } & \multicolumn{3}{|c|}{ DOC } & \multicolumn{3}{|c|}{$\mathrm{NO}_{3}-\mathrm{N}$} & \multicolumn{3}{|c|}{ DON } \\
\hline & mean $\pm \mathrm{SD}$ & $\min$ & $\max$ & mean $\pm \mathrm{SD}$ & $\min$ & $\max$ & mean $\pm \mathrm{SD}$ & $\min$ & $\max$ \\
\hline & \multicolumn{9}{|c|}{$\mathrm{mg} \mathrm{L}^{-1}$} \\
\hline $2005 / 2006$ & n.d. & n.d. & n.d. & $8.1 \pm 5.1$ & 0 & 15.9 & n.d. & n.d. & n.d. \\
\hline Winter & n.d. & n.d. & n.d. & $9.5 \pm 4.6$ & 0 & 15.9 & n.d. & n.d. & n.d. \\
\hline Summer & n.d. & n.d. & n.d. & $2.5 \pm 2.4$ & 0 & 7.6 & n.d. & n.d. & n.d. \\
\hline $2006 / 2007$ & $26.7 \pm 6.6$ & 15.1 & 47.7 & $9.6 \pm 6.0$ & 0 & 25.5 & $2.3 \pm 0.7$ & 0.7 & 6.2 \\
\hline Winter & $27.3 \pm 6.7$ & 15.4 & 39.4 & $10.9 \pm 6.4$ & 0 & 25.5 & $2.1 \pm 0.6$ & 0.7 & 3.8 \\
\hline Summer & $25.2 \pm 6.2$ & 15.1 & 47.7 & $6.9 \pm 4.1$ & 0 & 13.0 & $2.7 \pm 0.8$ & 1.5 & 6.2 \\
\hline $2007 / 2008$ & $22.6 \pm 3.7$ & 13.1 & 30.6 & $12.6 \pm 4.4$ & 0.2 & 21.2 & $2.6 \pm 0.8$ & 0.9 & 5.2 \\
\hline Winter & $22.5 \pm 3.7$ & 13.1 & 30.6 & $13.1 \pm 3.7$ & 5.6 & 21.2 & $2.6 \pm 0.8$ & 0.9 & 5.2 \\
\hline Summer & $24.4 \pm 0.8$ & 23.5 & 25.5 & $3.6 \pm 3.1$ & 0.2 & 9.1 & $1.9 \pm 0.2$ & 1.7 & 2.1 \\
\hline
\end{tabular}

more degraded than in the centre of the field. Degraded peat is especially prone to high DOC losses under re-wetting conditions (Kalbitz and Geyer, 2002; Zak and Gelbrecht, 2007). Although the number of concentration measurements in $2006 / 2007$ is too limited to draw final conclusions, the observed minor changes both in the groundwater and in the ditch suggest that no large additional DOC losses would have to be expected under re-wetting conditions.

According to the results of the GLS model (Table 5), deep groundwater tables and strong changes of the WTD result in higher DOC concentrations. Furthermore, there is a negative relationship between the $\mathrm{C}: \mathrm{N}$ ratio and the temperature. These results can be explained by higher mineralisation rates under these conditions and agree with results of other studies (e.g. Frank et al., 2014). The positive relationship with the groundwater table changes can be interpreted as a transport of DOC from the previously unsaturated zone towards the groundwater under conditions of a risen water table. Including the $\mathrm{pH}$ value into the analysis yielded an even more complex (and possibly overdetermined) model with high DOC concentrations corresponding to low $\mathrm{pH}$ values.

During the first two winters, $\mathrm{NO}_{3}-\mathrm{N}$ concentrations in some dip wells were extremely high (Fig. 4a), also compared to other studies. High $\mathrm{NO}_{3}-\mathrm{N}$ concentrations and losses can be explained by the intensive mineralisation of organic matter and subsequent nitrification in drained peatlands (Hacin et al., 2001; Höper, 2002). At our study site, $\mathrm{C}: \mathrm{N}$ ratios of 9-18 in $0-30 \mathrm{~cm}$ depth and additional fertiliser application create a favourable environment for nitrogen release. This is supported by the positive relationship between $\mathrm{N}$ concentrations of the peat and $\mathrm{NO}_{3}-\mathrm{N}$ concentrations in the dip wells (Table 5). Beetz and Glatzel (2013) measured net ecosystem exchange (NEE) at two grassland sites in our study area. Excluding harvest, they found gaseous $\mathrm{CO}_{2}-\mathrm{C}$ losses between around 4000 and $9000 \mathrm{~kg} \mathrm{ha}^{-1} \mathrm{a}^{-1}$. Assuming an average $\mathrm{C}: \mathrm{N}$ ratio of 14 this corresponds to $\mathrm{N}$ mineralisation rates of around 300 to $650 \mathrm{~kg} \mathrm{ha}^{-1} \mathrm{a}^{-1}$. Thus, high $\mathrm{NO}_{3}-\mathrm{N}$ concentrations are hardly surprising.

Although the concentration levels differed strongly between the single dip wells, $\mathrm{NO}_{3}-\mathrm{N}$ concentrations generally rose with rising GW levels (Table 5), and the temporal patterns were similar between the dip wells. This can be explained by mineralisation and subsequent nitrification during relatively dry periods followed by downward transport of $\mathrm{NO}_{3}-\mathrm{N}$ by rainfall events. Savard et al. (2007) showed in a dual-isotope study that winter nitrification can indeed be high. Snowmelt events tended to cause a dilution pattern (Tiemeyer et al., 2007), but significant snowmelt did occur only once during our study period.

While concentrations in the first two years were comparable, $\mathrm{NO}_{3}-\mathrm{N}$ concentrations were clearly lower during the third year of the study period, which can be explained by different hydrological conditions. Although small concentration peaks still occurred in the third winter at rising GW levels - or, better after lower GW levels - the wet summer of 2007 had by then completely changed the $\mathrm{NO}_{3}-\mathrm{N}$ concentration dynamics towards lower and more homogenous values in the groundwater. The drop of the $\mathrm{NO}_{3}-\mathrm{N}$ concentrations was especially evident at the dip wells in transect $\mathrm{C}$ (deep peat), while some dip wells in transect A with low SOC content were less affected (Fig. 4a). Due to the topography, these dip wells still showed low groundwater levels. The lowered $\mathrm{NO}_{3}-\mathrm{N}$ concentrations can be explained by denitrification during prolonged periods of high groundwater levels. A high denitrification potential is typical for degraded peatlands (Cabezas et al., 2012; Davidsson et al., 2002). In laboratory studies, $\mathrm{NO}_{3}-\mathrm{N}$ was found to be depleted within days to weeks (Cabezas et al., 2012; Corstanje and Reddy, 2004). Additionally, and probably more important, as the GW levels during the winter of 2007/2008 itself were not exceptionally high (Table 2), decreased mineralisation during the preceding wet summer period may have led to lower $\mathrm{NO}_{3}-\mathrm{N}$ concentrations. Thus, the effect of the high groundwater table in 
Table 5. Coefficients of the GLS (DOC) and LME $\left(\mathrm{NO}_{3}-\mathrm{N}\right)$ model for the $\mathrm{DOC}$ and the $\mathrm{NO}_{3}-\mathrm{N}$ concentrations in the groundwater samples. WTD - water table depth; $\Delta$ WTD - change of the WTD within the last week; WTD $_{30}$ - average WTD of the last 30 days; $T$ - air temperature; $T_{30}$ - average air temperature of the last 30 days; dist - distance to the drainage ditch; $\mathrm{N}$ - nitrogen content of the topsoil; SOC - soil organic carbon content of the topsoil; $\mathrm{CN}-\mathrm{C}: \mathrm{N}$ ratio of the topsoil; period - wet or dry period.

\begin{tabular}{|c|c|c|c|c|c|c|}
\hline \multirow[t]{2}{*}{ Parameter } & \multicolumn{2}{|c|}{ DOC } & \multicolumn{2}{|c|}{ DOC (with pH) } & \multicolumn{2}{|c|}{$\mathrm{NO}_{3}-\mathrm{N}$} \\
\hline & Value & $p$ & Value & $p$ & Value & $p$ \\
\hline WTD & 66.84 & $<0.0001$ & 176.81 & $<0.0001$ & -11.03 & $<0.0001$ \\
\hline$\Delta \mathrm{WTD}$ & 63.28 & 0.0382 & 136.23 & 0.0009 & -4.30 & $<0.0001$ \\
\hline $\mathrm{WTD}_{30}$ & & & 10.62 & 0.7850 & & \\
\hline$T$ & -0.30 & 0.3471 & -0.94 & 0.0008 & 0.02 & 0.4634 \\
\hline$T_{30}$ & 5.65 & 0.0001 & -18.75 & 0.0373 & & \\
\hline dist & & & 0.56 & $<0.0001$ & & \\
\hline $\mathrm{N}$ & 4.91 & $<0.0001$ & 8.93 & $<0.0001$ & 0.44 & 0.0001 \\
\hline SOC & & & & & -0.56 & 0.0012 \\
\hline $\mathrm{CN}$ & -13.62 & $<0.0001$ & -25.22 & $<0.0001$ & & \\
\hline $\mathrm{pH}$ & & & -14.71 & 0.0536 & & \\
\hline period & & & & & 6.48 & $<0.0001$ \\
\hline WTD : $T_{30}$ & -10.08 & 0.0007 & -51.05 & $<0.0001$ & & \\
\hline$\Delta \mathrm{WTD}: T$ & 21.90 & $<0.0001$ & 15.40 & $<0.0001$ & 0.69 & $<0.0001$ \\
\hline$\Delta \mathrm{WTD}: T_{30}$ & -35.49 & 0.0001 & -59.46 & $<0.0001$ & & \\
\hline $\mathrm{WTD}_{30}: T_{30}$ & & & 36.33 & 0.0001 & & \\
\hline$T_{30}: \mathrm{pH}$ & & & 3.57 & 0.0066 & & \\
\hline$T: \mathrm{N}$ & & & & & 0.005 & 0.0003 \\
\hline
\end{tabular}

summer is crucial for re-wetting projects, which should focus on wet conditions during summer when targeting nitrate retention.

Besides the wet summer, the variability of the groundwater table plays an important role for the $\mathrm{NO}_{3}-\mathrm{N}$ concentrations. The importance of fluctuating water levels for nitrogen mineralisation has been shown in laboratory studies (Corstanje and Reddy, 2004), but is difficult to quantify in the field. Compared to transects $\mathrm{A}$ and $\mathrm{C}$, the water level fluctuations in transect B were relatively gentle (Fig. 4b), which resulted in clearly lower $\mathrm{NO}_{3}-\mathrm{N}$ peaks even in the first two years of the study period. In transect $\mathrm{C}$, the groundwater table was less variable in the last year of the study period (Table 2), which in addition to the wet summer seemed to prevent mineralisation and subsequent nitrification in times of lower water tables.

Overall, the LME model seems to summarise these observations (Table 5): the depth to the groundwater table, the change of the groundwater table and the nitrogen content of the peat were the most important parameters. Interactions of the temperature with the $\mathrm{N}$ content of the soil and the groundwater table change probably indicate the enhanced mineralisation and nitrification under warmer conditions.

\subsection{Controls on DOC and N dynamics in the ditch: anthropogenic effects}

DOC concentrations in the ditch (Table 4) were lower than in the groundwater, which is not surprising as the dip wells of transect $\mathrm{C}$ were installed in the part of the catchment with the highest SOC content (on average, $368 \mathrm{~g} \mathrm{~kg}^{-1}$ at $0-30 \mathrm{~cm}$ and $452 \mathrm{~g} \mathrm{~kg}^{-1}$ at $60-90 \mathrm{~cm}$ depth; Tiemeyer et al., 2007) and the deepest peat layer.

The average concentrations of $24.9 \mathrm{mg} \mathrm{L}^{-1}$ are quite high for a lowland peatland, especially given that only a part of the catchment is covered by organic soils. While in disturbed bogs sometimes much higher concentrations have been measured (Frank et al., 2014), undisturbed sites clearly show lower DOC concentrations in the runoff water (Austnes et al., 2010; Dawson et al., 2002; Koehler et al., 2009). Kløve et al. (2010) measured comparable concentration in drainage pipes of agriculturally used peatlands. Data on comparable fen sites are largely missing. There is no clear effect of the dry or wet period on the DOC concentrations, which reflects the unchanged concentrations in the groundwater. Furthermore, the relatively high - and in the last year nearly undiluted - concentrations in the ditch strongly support the interpretation that the part of the catchment with organic soils is the main source of water for the ditch.

The highest concentrations were measured in the beginning of the study period, suggesting a flush of porewater enriched with DOC as soon as flow towards the ditch is initiated. In contrast to some other studies (Austnes et al., 2010) where DOC concentrations were found to increase with increasing discharge rates, we could not find such a pattern in our catchment (Fig. 2). The reason for this difference can be found in the different hydrological processes resulting in discharge generation: while the catchment studied by Austnes 
et al. (2010) was covered by blanket peats with a fast response and highly conductive surface layers on sloped terrain, our site is essentially flat and dominated by tile and ditch drainage. Residence time is suggested as a further controlling factor for DOC concentrations (Limpens et al., 2008), and indeed we found the best correlation of DOC to the average discharge over the last 60 to 80 days (Fig. 5). This is supported by the GLS model for the complete data set and the subset with EC measurements where $Q_{70}$ was found to be the only significant influence factor. This permits the interpretation that at higher discharge rates (and high groundwater level) over weeks the water has a shorter contact time with the peat, and less DOC is available for transport. If, in contrast, the water movement is slow, there will be a longer contact time with the peat, and thus an enrichment of the porewater with DOC. Additionally, times of slow water movement frequently coincide with aeration and increased mineralisation.

Only for the data subset with $\mathrm{pH}$ measurements the $\mathrm{pH}$ value, the temperature and the EC were included into the GLS model. Although removing these parameters from the model led to a lower NSC, especially the interaction terms are difficult to interpret, and the model might be overdetermined.

In the ditch, there was a negative correlation between DOC and $\mathrm{NO}_{3}-\mathrm{N}$ concentrations. The different pattern can be explained as, during periods of long residence time, DOC is accumulated in the groundwater while $\mathrm{NO}_{3}-\mathrm{N}$ is denitrified, especially if - as in summer - the tile drains are no longer active and higher temperatures promote biological activity. Indeed, low concentrations of $\mathrm{NO}_{3}-\mathrm{N}$ in the ditch were mainly measured during summer, especially in the dry summers 2006 and 2008, when, in addition to the processes in the groundwater, uptake by plants with a high biomass (Phragmites australis L.) in the ditches might remove nitrogen from the slowly flowing water, effectively acting as a "treatment wetland".

During the complete study period, the $\mathrm{NO}_{3}-\mathrm{N}$ concentrations in the ditch were high, and $47 \%$ of all samples exceeded the drinking water limit of $11.3 \mathrm{mg} \mathrm{L}^{-1}$. Only $11 \%$ of the samples were lower than $2.5 \mathrm{mg} \mathrm{L}^{-1}$, which corresponds to "moderate pollution" (LAWA, 1998) and the general German water quality target also in the context of the Water Framework Directive (UBA, 2010). These high concentrations are even more serious as there is no dilution at high discharge rates, but instead a clear positive correlation between the discharge and the $\mathrm{NO}_{3}-\mathrm{N}$ concentrations. Therefore, large volumes of water carry high $\mathrm{NO}_{3}-\mathrm{N}$ concentrations: $99 \%$ of the water volume leaving the catchment has concentrations higher than $2.5 \mathrm{mg} \mathrm{L}^{-1}$, and $66 \%$ of it exceeds the drinking water limit.

Cross-correlation analysis showed the strongest correlation between $\mathrm{NO}_{3}-\mathrm{N}$ and discharge for a lag time of a few days, while the highest concentrations generally coincide with the discharge peak. These seemingly contrasting results can be explained by a strong hysteresis: at the same discharge rate, $\mathrm{NO}_{3}-\mathrm{N}$ concentrations were higher at the falling limb of the hydrograph. A clear example for the hysteresis is the discharge event with a peak on 28 March 2006 (Fig. 2). The hysteresis can be explained by the occurrence of the highest $\mathrm{NO}_{3}-\mathrm{N}$ concentrations in the groundwater during times of a high groundwater table or directly thereafter during the first two years. As a result, the temporal $\mathrm{NO}_{3}-\mathrm{N}$ concentration patterns in the ditch were similar to the GW during these years.

The interpretation of the discharge being the most important controlling factor for the $\mathrm{NO}_{3}-\mathrm{N}$ concentrations is supported by $Q_{13}$ being the main factor in the GLS model for the complete data set and the subset with EC measurements. In both cases, the discharge at the day of the concentration measurement has a negative relationship with the $\mathrm{NO}_{3}-\mathrm{N}$ concentrations, which reflects hysteresis effects. As in the case of DOC, the data subset with $\mathrm{pH}$ measurements seems to be too small to allow plausible interpretations of the resulting complex model.

The $\mathrm{NO}_{3}-\mathrm{N}$ concentration patterns are strongly influenced by the presence of tile drains in the catchment, which directly discharge water into the ditches. First of all, ongoing drainage causes peat mineralisation and thus nitrogen mineralisation, which can be followed by nitrification. Tile drain discharge is generally highest under high groundwater levels. These were those phases when, during the first two years of the study period, $\mathrm{NO}_{3}-\mathrm{N}$ concentrations were highest. Thus, tile drainage may cause the water with high $\mathrm{NO}_{3}-\mathrm{N}$ concentrations to bypass the deeper anaerobic peat layers, where denitrification could have happened. Due to the transit through saturated zones of peat depleted in oxygen, sometimes even in agriculturally used catchments, especially under acidic soil conditions, low concentrations of $\mathrm{NO}_{3}-\mathrm{N}$ were measured (Frank et al., 2014; Sapek et al., 2007; van Beek et al., 2007). Due to the tile drains which have previously been found to carry high $\mathrm{NO}_{3}-\mathrm{N}$ concentrations (Roberts et al., 1986), the responsible processes do not fully work here. This interpretation is supported by lysimeter studies which also lack a prolonged transfer through the saturated zone. While Ross et al. (1995) measured, depending on the fertilisation level, $\mathrm{NO}_{3}-\mathrm{N}$ concentrations of 0 $44 \mathrm{mg} \mathrm{L}^{-1}$, Bergström and Johansson (1991) even found values $>100 \mathrm{~m} \mathrm{~L}^{-1}$ in the lysimeter leachate.

During the last winter of the study period, there was a strong contrast between the $\mathrm{NO}_{3}-\mathrm{N}$ concentrations in the groundwater and the ditches, i.e. the catchment outlet and ditch directly adjacent to transect $\mathrm{C}$. While the groundwater concentrations were diminished by the wet conditions in the preceding summer, the ditch concentrations were even higher (Fig. 4a). These results raise the question of why the relationship between the ditch dynamics and the GW dynamics changed in the last year of the study (Fig. 7): there was still a close relationship between the average $\mathrm{NO}_{3}-\mathrm{N}$ concentrations in the GW and the $\mathrm{NO}_{3}-\mathrm{N}$ concentrations in the 


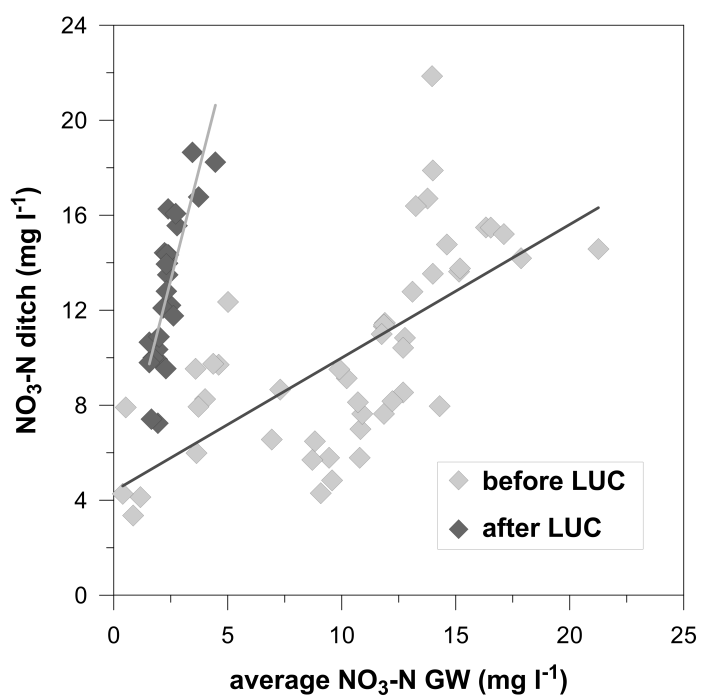

Figure 7. Relationship between the average nitrate-nitrogen $\left(\mathrm{NO}_{3}-\right.$ $\mathrm{N}$ ) concentrations in the dip wells and the $\mathrm{NO}_{3}-\mathrm{N}$ concentrations in the ditch before and after land use change (LUC). $\mathrm{NO}_{3}-\mathrm{N}$ concentrations of the ditch are 10-day means starting on the date of dip well sampling.

ditch, but the slope greatly changed. This suggests that the processes in the part of the catchment where the dip wells are situated were still important for the catchment response, but that an additional source of $\mathrm{NO}_{3}-\mathrm{N}$ appeared during the last year of the study.

We suggest that there are two reasons for this observation: in the last year of the study period we observed, unintentionally, the effects of the superposition of changed hydrological conditions - which became apparent in the groundwater concentrations - and land use change, which determined the ditch concentration level and the change in the ditch-GW relationship: firstly, a part of the grassland was converted to arable land for maize production in spring 2007. Ploughingup of grassland can lead to mobilisation of nitrate even from mineral soils (Sheperd et al., 2001). In an upland pasture on peat, nitrate losses were increased by around $70 \%$ even three years after ploughing and reseeding (Roberts et al., 1986). Secondly, the summer of 2007 was exceptionally wet (Table 2), which caused farmers to renew the ditches and some of the tile drains. This also affected the freshly ploughed arable land. Although we did not directly measure leaching from this "new" arable land, this combination seems a plausible explanation for the high $\mathrm{NO}_{3}-\mathrm{N}$ concentration in the ditch despite decreasing concentrations in the groundwater of the grassland.

DON concentrations were relatively low. Factors influencing the DON concentrations were difficult to determine; there is only a very slight effect of the discharge or EC. There was also no correlation between DOC and DON in the ditch water, supporting the assumption that different processes govern the release of DOC and DON (Kalbitz and Geyer, 2002).
Furthermore, DON analysis will be challenging if, as in our case, high concentrations of dissolved inorganic nitrogen are present as errors of the analytical methods may add up and as total nitrogen analysis is prone to relatively low recovery rates under these conditions (e.g. Graeber et al., 2012; Vandenbruwane et al., 2007). Therefore, we had to accept some uncertainties in the DON measurements which we cannot quantify.

\subsection{DOC and nitrogen losses}

Annual DOC losses from peat catchments as measured by Dawson et al. (2002), Gibson et al. (2009), Kløve et al. (2010) and Koehler et al. (2009) are considerably higher $\left(108-191 \mathrm{~kg} \mathrm{ha}^{-1}\right.$ ) than our values (Fig. 6), but all these studies focussed on upland areas with high discharge rates. Results from Fraser et al. (2001) are closer $\left(83 \mathrm{~kg} \mathrm{ha}^{-1}\right)$ to ours, but their system - a northern bog - is very different to our site. Data on agriculturally used lowland peatlands with fen peat are surprisingly scarce, and we could find no data on comparable sites. Even if the DOC losses from our study site were not extraordinarily high, they could cause problems further downstream, i.e. for drinking water treatment. However, when comparing our DOC and $\mathrm{N}$ losses to other studies on peatlands, it has to be taken into account that only a part $(50 \%)$ of the catchment is covered by organic soils and that we cannot quantify a possible contribution of the groundwater pathway from the arable land. Given that the arable land is not tile-drained and on mineral soils, we assume low DOC losses from this part of the catchment as well as efficient denitrification during the passage towards the peatland and the ditches.

We measured higher DOC losses in the wetter year (Fig. 6), but this was solely controlled by the discharge rates, not by the concentrations in the ditch or in the groundwater. As the groundwater concentrations remained largely unchanged by the extreme meteorological conditions, we would expect, at least in the short term, similar DOC losses under re-wetting conditions, especially if more water was retained in the catchment.

At two grassland sites within the catchment, Beetz and Glatzel (2013) measured a NEE of carbon dioxide between around 4000 and $9000 \mathrm{~kg} \mathrm{ha}^{-1}$. Thus, fluvial carbon losses of, on average, $53 \mathrm{~kg} \mathrm{ha}^{-1}$ do not play a large role for the total carbon budget of the catchment. Even assuming that the only origin of the DOC is the part of the catchment with organic soils, DOC only accounts for around $2 \%$ of the gaseous carbon losses. These results seemingly contrast with other studies where fluvial carbon losses form an important part of the carbon balance (Dinsmore et al., 2010). These near-natural catchments, however, have a significantly lower NEE resulting in a higher relative importance of the DOC losses. Moreover, they show higher discharge rates and thus higher DOC losses than our catchment. 
Although it is widely known that $\mathrm{NO}_{3}-\mathrm{N}$ can be released when peatlands are drained, there are surprisingly few studies actually providing numbers. The value $\left(38 \mathrm{~kg} \mathrm{~N} \mathrm{ha}^{-1} \mathrm{a}^{-1}\right)$ given by van Beek et al. (2007) for an experimental field in the Netherlands, however, is comparable to our results. Even under drained conditions, nitrate losses even from agriculturally used peatlands are sometimes quite low as the water passes the permanently saturated part of the peat where optimal conditions for denitrification prevail (Kløve et al., 2010). However, in our case the tile drains in parts of the catchment seem to cause an effective bypass of the saturated zone. The superposition of hydrological and management effects are probably the reason why the wet conditions from June 2007 to April 2008 were not reflected by decreasing $\mathrm{NO}_{3}-\mathrm{N}$ losses from the catchment. Our values are lower than those of the lysimeter studies of Behrendt et al. (1996) and Roberts et al. (1986), who measured annual losses of more than 100 $\mathrm{kg} \mathrm{NO}_{3}-\mathrm{N} \mathrm{ha}^{-1}$. These higher values might be explained by the methodological differences and, in the case of Roberts et al. (1996), much higher precipitation. Lysimeter discharge and losses from Bergström and Johansson (1991) are, however, comparable to our results, while Ross et al. (1985) found clearly lower losses $\left(1-14 \mathrm{~kg} \mathrm{NO}_{3}-\mathrm{Nha}^{-1} \mathrm{a}^{-1}\right)$ from their lysimeters, but they report neither on discharge nor water table levels. In the regional context, the $\mathrm{NO}_{3}-\mathrm{N}$ losses are as high as or higher than losses from tile-drained arable land on mineral soils, which is widely found to be important for $\mathrm{N}$ pollution (Tiemeyer et al., 2006).

Compared to theoretical losses between 300 and $650 \mathrm{~kg} \mathrm{ha}^{-1} \mathrm{a}^{-1}$ and an additional average field nitrogen budget of $81 \mathrm{~kg} \mathrm{ha}^{-1} \mathrm{a}^{-1}$ (Table 1), substantial amounts of mineral $\mathrm{N}$ have to be denitrified or immobilised within the peatland. Van Beek et al. (2007), for example, estimate an annual denitrification of $213 \mathrm{~kg} \mathrm{Nha}^{-1}$. Due to the high spatial variability it is difficult to assess how much $\mathrm{NO}_{3}-\mathrm{N}$ produced in the unsaturated zone is denitrified on its pathway to the ditches. Similarly, there might be input by groundwater flow or leaching to the deeper groundwater, which we cannot quantify.

Compared to DOC and $\mathrm{NO}_{3}-\mathrm{N}$, there is even less information on DON losses from lowland peatland catchments. In a near-natural blanked bog catchment, Adamson et al. (1998) measured DON losses in the same range (5.7 to $6.5 \mathrm{~kg} \mathrm{ha}^{-1} \mathrm{a}^{-1}$ ) as our values, but these are the result of much lower DON concentrations and higher discharge rates. As mineral nitrogen concentrations were very low in this study, DON formed $85 \%$ of the total nitrogen losses. Also in a catchment with high discharge rates, Kløve et al. (2010) measured average DON losses of $11 \mathrm{~kg} \mathrm{ha}^{-1} \mathrm{a}^{-1}$ from drained peat, corresponding to $50 \%$ of the $\mathrm{N}$ losses. Results in our catchments were the other way round in both years as DON losses accounted for around $15 \%$ of the TN losses. Nonetheless, DON may form a relevant component of the $\mathrm{N}$ balance of drained peatland catchments and even more so of re-wetted peatlands with decreased $\mathrm{NO}_{3}-\mathrm{N}$ con- centrations. In addition, the controls on the DON concentration dynamics are not clear, so the topic seems to call for further attention.

\section{Conclusions}

We measured DOC and $\mathrm{N}$ concentrations in and losses from a grassland peatland under changing conditions. While the situation during the first 1.5 years was typical for the region, the remainder of the study period saw a superposition of very wet conditions (in its effects, similar to re-wetting) and land use change. The results suggest that under re-wetting conditions groundwater $\mathrm{NO}_{3}-\mathrm{N}$ concentrations would decrease very quickly, while DOC concentrations would remain on a similar level. Relatively, DOC losses did not constitute a major part of the carbon balance, but this is mainly because of the high NEE of a drained peatland, as the losses themselves are comparable to other studies. In this case, summer groundwater levels and groundwater table fluctuations decide on $\mathrm{NO}_{3}-\mathrm{N}$ concentrations in the subsequent winter. Further intensification of the land use, on the other hand, might increase the $\mathrm{NO}_{3}-\mathrm{N}$ losses to receiving waters. DON accounted for around $15 \%$ of the total $\mathrm{N}$ losses, but factors influencing DON concentrations deserve further study. In the light of the European Water Framework Directive, re-wetting peatlands is a valuable tool for reducing $\mathrm{N}$ losses to lowland rivers.

Acknowledgements. We would like to thank Susanne Behn, Marianne Kietzmann, Monika Hopp and Sabine Wathsack for laboratory analyses and Tilo Hartwig for his assistance with the fieldwork. Sascha Beetz provided us with vegetation data. The German Weather Service provided meteorological data. Stefan Frank is to be thanked for discussion on statistical matters. DOC and TN measurements were financially supported by the joint research project "Organic soils" funded by the Thünen Institute.

Edited by: T. Laurila

\section{References}

Adamson, J. K., Scott, W. A., and Rowland, A. P.: The dynamics of dissolved nitrogen in a blanket peat dominated catchment, Environ Pollut, 0, 69-77, 1998.

Åström, M., Aaltonen, E.-K., and Koivusaari, J.: Changes in leaching patterns of nitrogen and phosphorus after drainage of boreal forest - a paired catchment study on Lappajärvi, western Finland, Boreal Environ. Res., 10, 67-78, 2004.

Austnes, K., Evans, C. D., Eliot-Laze, C., Naden, P. S., and Old, G. H.: Effects of storm events on mobilization and in-stream processing of dissolved organic matter (DOM) in a Welsh peatland catchment, Biogeochemistry, 99, 157-173, 2010.

Beetz, S. and Glatzel, S.: Endbericht der Teilgruppe "UHRO" des Verbundprojektes "Organische Böden" des Johann Heinrich von Thünen-Institutes, Unpublished report, 2013. 
Behrendt, A., Mundel, G., Schalitz, G., and Hölzel, D.: 25 Jahre Lysimeterforschung in Paulinenaue und Neukonzipierung der Untersuchungen (1992), ZALF-Berichte, 26, 6-27, 1996.

Behrendt, H.: Quantifizierung der Nährstoffeinträge aus Flußgebieten des Landes Mecklenburg-Vorpommerns, Landesamt für Umwelt und Naturschutz und Geologie MecklenburgVorpommern, Güstrow, 1996.

Bergström, L. and Johansson, R.: Leaching of nitrate from monolith lysimeters of different types of agricultural soils, J. Environ. Qual., 20, 801-807, 1991.

Blume, S.: Stoffaustrag aus landwirtschaftlichen Flächen im Einzugsbereich der Warnow unter Berücksichtigung des Bodeninventars, Unpublished diploma thesis, Faculty of Agricultural and Environmental Sciences, Rostock University, 2005.

Cabezas, A., Gelbrecht, J., Zwirnmann, E., Barth, M., and Zak, D.: Effects of degree of peat decomposition, loading rate and temperature on dissolved nitrogen turnover in rewetted fens, Soil Biol. Biochem., 48, 182-191, 2012.

Cabezas, A., Gelbrecht, J., and Zak, D.: The effect of rewetting drained fens with nitrate-polluted water on dissolved organic carbon and phosphorus release, Ecol. Eng., 53, 79-88, 2013.

Chow, A. T., Tanji, K. K., and Gao, S.: Production of dissolved organic carbon (DOC) and trihalomethane (THM) precursor from peat soils, Wat. Res., 37, 4475-4485, 2003.

Clark, J. M., Chapman, P. J., Adamson, J. K., and Lane, S. N.: Influence of drought-induced acidification on the mobility of dissolved organic carbon in peat soil, Glob. Change Biol., 11, 791809,2005

Corstanje, R. and Reddy, K. R.: Response of biogeochemical indicators to a drawdown and subsequent reflood, J. Environ. Qual., 33, 2357-2366, 2004.

Davidsson, T. E., Trepel, M., and Schrautzer, J.: Denitrification in drained and rewetted minerotrophic peat soils in Northern Germany (Pohnsdorfer Stauung), J. Plant. Nutr. Soil. Sci., 165, 199204, 2002.

Dawson, J. J. C., Billet, M. F., Neal, C., and Hill, S.: A comparison of particulate, dissolved and gaseous carbon in two contrasting upland streams in the UK, J. Hydrol., 257, 226-246, 2002.

Dinsmore, K., Billet, M. F., Skiba, U. M., Rees, R. M., Drewer, J., and Helfter, C.: Role of the aquatic pathway in the carbon and greenhouse gas budgets of a peatland catchment, Glob. Change Biol., 16, 2750-2762, 2010.

Edom, F., Dittrich, I., Keßler, K., Münch, A., and Wahren, A.: vTIVerbundprojekt "Organische Böden": Testgebietskompendium Dummerstorf DU Teil Hydrologie, Unpublished report, 2010.

European Parliament and European Council: Directive 2000/60/EC of the European Parliament and of the Council of October 2000 establishing a framework for Community action in the field of water policy, Official J. Eur. Com., L327, 1-73, 2000.

Evans, C. D., Chapman, P. J., Clark, J. M., Monteith, D. T., and Cresser, M. S.: Alternative explanations for rising dissolved organic carbon export from organic soils, Glob. Change Biol., 12, 2044-2053, 2006.

Fiedler, S., Höll, B. S., Freibauer, A., Stahr, K., Drösler, M., Schloter, M., and Jungkunst, H. F.: Particulate organic carbon (POC) in relation to other pore water carbon fractions in drained and rewetted fens in Southern Germany, Biogeosciences, 5, 1615-1623, doi:10.5194/bg-5-1615-2008, 2008.
Frank, S., Tiemeyer, B., Gelbrecht, J., and Freibauer, A.: High soil solution carbon and nitrogen concentrations in a drained Atlantic bog are reduced to natural levels by 10 years of rewetting, Biogeosciences, 11, 2309-2324, doi:10.5194/bg-11-2309-2014, 2014.

Fraser, C. J. D., Roulet, N. T., and Moore, T. R.: Hydrology and dissolved organic carbon biogeochemistry in an ombotrophic bog, Hydrol. Process., 15, 3151-3166, 2001.

Gibson, H. S., Worrall, F., Burt, T. P., and Adamson, J. K.: DOC budgets of drained peat catchments: implications for DOC production in peat soils, Hydrol. Process., 23, 1901-1911, 2009.

Gorham, E.: Northern peatlands: role in the carbon-cycle and probable responses to climatic warming, Ecol. Appl., 1, 182-195, 1991.

Graeber, D., Gelbrecht, J., Kronvang, B., Gücker, B., Pusch, M. T., and Zwirnmann, E.: Technical Note: Comparison between a direct and the standard, indirect method for dissolved organic nitrogen determination in freshwater environments with high dissolved inorganic nitrogen concentrations, Biogeosciences, 9, 4873-4884, doi:10.5194/bg-9-4873-2012, 2012.

Hacin, J., Čop, J., and Mahne, I.: Nitrogen mineralization in marsh meadows in relation to organic matter content and watertable level, J. Plant. Nutr. Soil. Sci., 164, 503-509, 2001.

Holden, J., Chapman, P. J., and Labadz, J. C.: Artificial drainage of peatlands: hydrological and hydrochemical process and wetland restoration, Prog. Phys. Geog., 28, 95-123, 2004.

Höper, H.: Carbon and nitrogen mineralisation rates of fens in Germany used for agriculture. A review, in: Wetlands in Central Europe, edited by: Broll, G., Merbach, W., and Pfeiffer, E. M., 149164, Springer, Berlin, 2002.

IUSS Working Group WRB.: World Reference Base for Soil Resources 2006, first update 2007, World Soil Resources Reports No. 103, FAO, Rome, 2007.

Kalbitz, K. and Geyer, S.: Different effects of peat degradation on dissolved organic carbon and nitrogen, Org. Geochem., 33, 319326, 2002.

Kløve, B., Sveistrup, T. E., and Hauge, A.: Leaching of nutrients and emission of greenhouse gases from peatland cultivation at Bodin, Northern Norway, Geoderma 154, 219-232, 2010.

Koehler, A.-K., Murphy, K., Kiely, G., and Sottocornola, M.: Seasonal variation of DOC concentration and annual loss of DOC from an Atlantic blanket bog in South Western Ireland, Biogeochemistry, 95, 231-242, 2009.

LAWA (Working Group on water issues of the Federal States and the Federal Government represented by the Federal Environment Ministry, Ed.): Bewertung der Wasserbeschaffenheit von Fließgewässern in der Bundesrepublik Deutschland chemische Gewässergüteklassifikation, Kulturbuchverlag Berlin GmbH, Berlin, Germany, 1998.

Limpens, J., Berendse, F., Blodau, C., Canadell, J. G., Freeman, C., Holden, J., Roulet, N., Rydin, H., and Schaepman-Strub, G.: Peatlands and the carbon cycle: from local processes to global implications - a synthesis, Biogeosciences, 5, 1475-1491, doi:10.5194/bg-5-1475-2008, 2008.

Martin, H. W., Ivanoff, D. B., Graetz, D. A., and Reddy, K. R.: Water table effects on histosol drainage water carbon, nitrogen and phosphorus, J. Environ. Qual., 26, 1062-1071, 1997.

MELFF MV (Ministerium für Ernährung, Landwirtschaft, Forsten und Fischerei Mecklenburg-Vorpommern, Eds.).: Düngung - 
Hinweise und Richtwerte für die landwirtschaftliche Praxis, Leitfaden zur Umsetzung der Düngeverordnung, Rostock, 2004.

Nash, J. E. and Sutcliffe, J. V.: River flow forecasting through conceptual models, Part I: a discussion of principles, J. Hydrol., 10, 282-290, 1970.

Okruszko, H.: Wirkung der Bodennutzung auf die Niedermoorbodenentwicklung, Ergebnisse eines langjährigen Feldversuches, Zeitsch. Kulturtech. Landentwick., 30, 167-176, 1989.

Olde Venterink, H., Davidson, T. E., Kiehl, K., and Leonardson, L.: Impact of drying and re-wetting on $\mathrm{N}, \mathrm{P}$ and $\mathrm{K}$ dynamics in a wetlands soil, Plant Soil, 243, 119-130, 2002.

Pinheiro, J., Bates, D., DebRoy, S., Sarkar, D., and the R Development Core Team: nlme: Linear and Nonlinear Mixed Effects Models, R package version 3.1-109, 2013.

$\mathrm{R}$ Core Team: R: A language and environment for statistical computing. R Foundation for Statistical Computing, Vienna, Austria, http://www.R-project.org/, 2013.

Roberts, G., Hudson, J. A., and Blackie, J. R.: Effects of upland pasture improvement on nutrient release in flows from a "natural" lysimeter and a field drain, Agr. Water Manage., 11, 231-245, 1986.

Ross, S. M., Beadle, R. S., and Jewkes, E.: Lysimeter studies of nitrogen leaching potential in wetland peats and clays in SouthWest Britain, in: Hydrology and Hydrochemistry of British Wetlands, edited by: Hughes, J. M. R. and Heathwaite, A. L., 224243, John Wiley \& Sons Ltd, Chichester, 1995.

Rothwell, J. J., Evans, M. G., Daniels, S. M., and Allot, T. E. H.: Baseflow and stormflow metal concentrations in streams draining contaminated peat moorlands in the Peak District National Park (UK), J. Hydrol., 341, 90-104, 2007.

Rowson, J. G., Gibson, H. S., Worrall, F., Ostle, N., Burt, T. P, and Adamson, J. K.: The complete carbon budget of a drained peat catchment, Soil Use Manage., 26, 261-273, 2010.

Russi, D., ten Brink, P., Farmer, A., Badura, T., Coates, D., Förster, J., Kumar, R., and Davidson, N.: The economics of ecosystems and biodiversity for water and wetlands, IEEP, London and Brussels, Ramsar Secretariat, Gland, 2013.

Sapek, A., Sapek, B., Chrzanowski, S., and Jaszczyński, J.: Mobilzation of substances in peat soils and their transfer within the groundwater and into surface water, Agron. Res., 5, 155-163, 2007.

Savard, M. M., Paradis, D., Somers, G., Liao, S., and van Bochove, E.: Winter nitrification contributes to excess $\mathrm{NO}_{3}^{-}$in groundwater of an agricultural region: A dual-isotope study, Water Resour. Res., 43, W06422, doi:10.1029/2006WR005469, 2007.

Sheperd, M. A., Hatch, D. J., Jarvis, S. C., and Bhogal, A.: Nitrate leaching from reseeded pasture, Soil Use Manage., 17, 97-105, 2001 .
Succow, M. and Joosten, H. (Eds.): Landschaftsökologische Moorkunde, 2nd edition, E. Schweizerbart'sche Verlagsbuchhandlung, Stuttgart, Germany, 2001.

Tiemeyer, B., Kahle, P., and Lennartz, B.: Nutrient losses from artificially drained catchments in North-Eastern Germany at different scales, Agr. Water Manage., 85, 47-57, 2006.

Tiemeyer, B., Frings, J., Kahle, P., Köhne, S., and Lennartz, B.: A comprehensive study of nutrient losses, soil properties and groundwater concentrations in a degraded peatland used as an intensive meadow - implications for re-wetting, J. Hydrol., 345, 80-101, 2007.

Trepel, M.: Assessing the cost-effectiveness of the water purification function of wetlands for environmental planning, Ecol. Complex., 7, 320-326, 2010.

UBA (Federal Environment Agency): Water Resource Management in Germany Part 2 - Water Quality, Dessau, Germany, 2010.

UBA (Federal Environment Agency): National inventory report for the German Greenhouse Gas Inventory 1990-2010, Submission under the United Nations Framework Convention on Climate Change and the Kyoto Protocol 2012, Dessau, Germany, 2012.

Van Beek, C. L., Droogers, P., van Hardeveld, H. A., van den Eertwegh, G. A. P. H., Velthof, G. L., and Oenema, O.: Leaching of solutes from an intensively managed peat soil to surface water, Water Air Soil Pollut., 182, 291-301, 2007.

Vandenbruwane, J., De Neve, S., Qualls, R. G., Salomez, J., and Hofman, G.: Optimization of dissolved organic nitrogen (DON) measurements in aqueous samples with high inorganic nitrogen concentrations, Sci. Total Environ., 386, 103-113, 2007.

Verhoeven, J. T. A., Keuter, A., van Logtestijn, R., van Kerkhoeven, M. B., and Wassen, R.: Control of local nutrient dynamics in mires by regional and climatic factors: a comparison of Dutch and Polish sites, J. Ecol., 84, 647-656, 1996.

Vikman, A., Sarkkola, S., Koivusalo, H., Sallantaus, T., Laine, J., Silvan, N., Nousiainen, H., and Nieminen, M.: Nitrogen retention by peatland buffer areas at six forested catchments in southern and central Finland, Hydrobiologia, 641, 171-183, 2010.

Wallage, Z. E., Holden, J., and McDonald, A. T.: Drain blocking: An effective treatment for reducing dissolved organic carbon loss and water discolouration in a drained peatland, Sci. Total Environ., 367, 811-821, 2006.

Zak, D. and Gelbrecht, J.: The mobilisation of phosphorus, organic carbon and ammonium in the initial stage of fen rewetting (a case study from NE Germany), Biogeochemistry, 85, 141-151, 2007.

Zeitz, J. and Velty, S.: Soil properties of drained and rewetted fen soils, J. Plant Nutr. Soil Sci., 165, 618-626, 2002.

Zuur, A. F., Ieno, E. N., Walker, N. J., Saveliev, A. A., and Graham, M. S.: Mixed Effects Models and Extensions in Ecology with R, 574 pp., Springer, 2009. 